Ewelina Parafińska-Korybska

(iD https://orcid.org/0000-0003-0508-0321

Katolicki Uniwersytet Lubelski Jana Pawła II

Wydział Nauk Humanistycznych

Instytut Językoznawstwa

Katedra Translatoryki i Języków Słowiańskich

20-950 Lublin, Al. Racławickie 14

e-mail: ewelina.parafinska@wp.pl

https://doi.org/10.18778/8220-520-6.14

\title{
PRZEKŁAD A SŁOWNIK. TEKSTY O TEMATYCE TEATRALNEJ I OPEROWEJ VS LEKSYKOGRAFIA POLSKO-ROSYJSKA
}

\author{
Translation in contrast to a dictionary. Theatrical \\ and opera texts versus Polish-Russian lexicography
}

\author{
ПеревоА и словарь. Тексты о театре и опере \\ в помьско-русской мексикографии
}

\begin{abstract}
Streszczenie
Głównym celem badań było sprawdzenie aktualności leksyki teatralnej i operowej w leksykografii polsko-rosyjskiej: Wielkim słowniku polsko-rosyjskim D. Hessena i R. Stypuły i Wielkim słowniku polsko-rosyjskim pod red. J. Wawrzyńczyka oraz Podręcznym idiomatykonie polsko-rosyjskim pod red. W. Chlebdy. Odnotowano obecność dużej liczby jednostek z zakresu teatru i opery ww. źródłach, którą uporządkowano według klas semantycznych. Stopień aktualności zasobów słownikowych sprawdzono na podstawie leksyki występującej w czasopismach: „Teatr” i „Opera Café”.

Współczesne teksty o tej tematyce obfitują jednak w liczne połączenia wyrazowe (często niestandardowe), których słowniki nie rejestrują, co świadczy o niewystarczającej funkcjonalności słowników.
\end{abstract}

\section{Summary}

The main aim of the research is to examine the topicality of theatrical and operatic lexis in Polish-Russian lexicography, D. Hessen and R. Stypuła's Wielki stownik polsko-rosyjski, Wielki stownik polsko-rosyjski edited by J. Wawrzyńczyk, and Podręczny idiomatykon polsko-rosyjski edited by W. Chlebda. The lexis to be studied was noted. The 
topicality degree of the dictionary resources was verified based on lexis found in the Teatr and Opera Café magazines. A large number of the units from the area of theatre and opera was noted in dictionaries. However, contemporary texts on this subject abound in numerous word combinations (often non-standard), which the dictionaries do not include. This indicates the insufficient functionality of the studied resources.

\section{Резюме}

ГАавной целью исследований явмялась проверка актуальности театральной и оперной мексики в польско-русской мексикографии - Wielkim stowniku polsko-rosyjskim А. Гессена и Р. Стыпулы и Wielkim stowniku polsko-rosyjkkim поА реА. Я. Вавжинчика, а также Podręcznym idiomatykonie polsko-rosyjskim поА реА. В. ХиебАы. Бымо отмечено наличие большого количества мексических единиц, тематически связанных с театром и оперой, разделенных по семантическим классам. Степень актуальности словарных ресурсов была проверена на основании нексики, которая присутствует в журналах: „Teatr” і „Opera Café”. Бымо замечено значительное количество единиц из области театра и оперы в словарях. Современные тексты на эту тему изобилуют однако многими словосочетаниями (в том числе нестандартными), которых нет в словарях. Это свидетельствует о том, что словари недостаточно функциональны.

Słowa kluczowe: leksyka teatralna, leksyka operowa, leksykografia, słowniki, czasopisma, aktualność leksyki.

Keywords: theatrical lexis, opera lexis, lexicography, dictionaries, magazines, topicality of lexis.

Кмючевые слова: театральная мексика, оперная мексика, Аексикография, словари, журналы, актуальность мексики.

W literaturze przedmiotu dotyczącej leksykografii niejednokrotnie wskazywano na braki w zasobach hasłowych słowników oraz na to, że słowniki nie zawsze są wystarczającą pomocą w codziennym posługiwaniu się językiem obcym, a zwłaszcza w tłumaczeniu. Podkreśla to m.in. С.В. Тюленев, który twierdzi, że błędne jest przeświadczenie o tym, iż znajomość podstaw języka obcego i wyposażenie się w słownik dwujęzyczny lub przekładowy to wystarczające środki do tego, by być tłumaczem. Zaznacza też, że dla doświadczonych tłumaczy sprawdzenie słowa w słowniku to najczęściej pierwszy, wstępny krok do poszukiwań właściwego odpowiednika (Тюленев, 2004, 285-286; por. Piotrowski, 2011, 50). Podobnie T. Piotrowski podaje w wątpliwość istnienie ekwiwalentów w tłumaczeniu - możemy to jednak odnieść również do leksykografii:

Słownik dwujęzyczny nie może naprawdę dać tłumaczowi prawidłowych ekwiwalentów, ponieważ ekwiwalenty są specyficzne dla danego tekstu, w dużej mierze są nieprzewidywalne, a ich liczba jest zbyt duża, by można je było umieścić w słowniku (Piotrowski, 2011, 47, 49). 
Badacz dodaje, że tekst przetłumaczony w dużej mierze za pomocą słownika, choć bywa zrozumiały, to najczęściej nie można go uznać za akceptowalny, naturalnie brzmiący w danym języku (tamże, 49). Niniejszy tekst wpisuje się w nurt twierdzeń krytycznych, jednak nie w odniesieniu do całości materiału leksykalnego, ale konkretnego typu leksyki zawartego w słownikach. Dyskurs krytyczny ma już swoją tradycję w badaniach nad leksykografią. Należy jednak podkreślić, broniąc się przed zarzutem o powtarzanie już wypowiedzianego, że leksyka teatralna i operowa, której poświęca się ten tekst, nie została jeszcze należycie zbadana pod kątem obecności w słownikach, podczas gdy rozwój kulturalny i artystyczny rodzi potrzebę tworzenia tekstów dotyczących teatru i opery w różnych językach. Warto więc nakreślić jej miejsce i stan w leksykografii polsko-rosyjskiej (bazując na wybranych reprezentacjach słowników), nawet jeżeli wnioski w dużej mierze pokryją się z tym, co o leksykografii w kontekście jej przydatności dla przekładu już wiemy.

Leksyka teatralna i operowa, w przeciwieństwie do słownictwa z branży technicznej czy informatycznej, nie podlega intensywnym zmianom, cechuje się dużym stopniem aktualności na przestrzeni lat. Można zatem postawić pytanie, czy taka leksyka wymaga uaktualniania przez leksykografów, czy też jej zasób może być stały i niezmienny, jako że słowniki notują wystarczającą liczbę jednostek z zakresu leksyki teatralnej i operowej do tego, by zaspokoić potrzeby użytkowników? Czy, zważywszy na zakładaną stabilność słownictwa teatralnego i operowego, jest ono w słownikach aktualne, a co za tym idzie, adekwatne do potrzeb użytkowników?

Celem niniejszego artykułu jest zatem zbadanie zasobów słownictwa dotyczącego teatru i opery w słownikach polsko-rosyjskich oraz sprawdzenie, w jakim stopniu ten zasób jest funkcjonalny. Do analizy wybrano dwa najobszerniejsze słowniki ogólne, tj. Wielki stownik polsko-rosyjski D. Hessena i R. Stypuły, wydawnictwa Wiedza Powszechna (zwany dalej WSPR WP) i Wielki stownik polsko-rosyjski pod redakcją J. Wawrzyńczyka, wydawnictwa PWN (zwany dalej WSPR PWN). Są to słowniki cieszące się wśród użytkowników popularnością, mimo że nie są to pozycje nowe. Zawierają one jednak dużą liczbę jednostek, w związku z czym mogą stanowić miarodajny obraz stanu leksyki zawartej w słownikach polsko-rosyjskich. Powzięto także decyzję o włączeniu do badań Podręcznego idiomatykonu polsko-rosyjskiego (zwanego dalej PIPR) z uwagi na nowatorskość tej pozycji - jest to tematyczny słownik przekładowy jednostek wyrazowych o charakterze praktycznym. Zebrano w nim słowa i wyrażenia odnoszące się do różnych dziedzin, nienotowane dotąd w słownikach dwujęzycznych czy przekładowych ${ }^{1}$ ogól-

1 Należy tu wyjaśnić, że pojęcia słownik dwujęzyczny i słownik przekładowy, które niejednokrotnie pojawią się w treści niniejszego tekstu, autor wyraźnie rozróżnia. Badacze niekiedy w bardzo odmienny sposób podchodzą do tego tematu, jednak nie jest to miejsce na prezentację stanu badań na ten temat. Ograniczymy się do przywołania nazwisk E. Kubickiej i A. Walkiewicz. Badaczki w swoim artykule przedstawiły syntezę 
nych ani frazeologicznych. Można stwierdzić, że różnorodność obszarów opracowanych na potrzeby kolejnych tomów wypełnia lukę tematyczną w leksykografii. Sprawdzimy, czy zostaje ona wypełniona także w interesujących nas dziedzinach - teatrze i operze, bowiem na rynku wydawniczym w Polsce brakuje dobrych specjalistycznych słowników, które byłyby poświęcone właśnie tej leksyce.

$\mathrm{Z}$ analizowanych pozycji leksykograficznych wyekscerpowano zatem leksykę teatralną i operową. Należy dodać, że choć związek opery z teatrem jest oczywisty, to z uwagi na fakt, iż opera zachowuje swoją odrębność i tradycję, zdecydowano o podkreśleniu jej wagi poprzez wymienienie tej dziedziny jako drugiego komponentu. Obie grupy w wielu przypadkach mają zbieżne leksemy, jednak uwzględnienie słownictwa operowego pozwala rozszerzyć zbiór leksyki o pojęcia właściwe tylko dla niej, które również wymagają analizy. Wyekscerpowana leksyka utworzyła pewien korpus, w którym można wyróżnić klasy semantyczne - przedstawimy je poniżej. Na początku należy jednak dodać, że korpus ten został sporządzony w oparciu o WSPR WP i WSPR PWN. PIPR był analizowany oddzielnie, co zostanie uzasadnione w dalszej części tekstu.

Zgromadzoną leksykę można ująć w następujące klasy semantyczne:

1) nazwy elementów dzieła teatralnego i operowego:

np.: aria, uwertura, akt, scena, didaskalia, ansambl, recytatyw, intermezzo, scena finatowa, odstona;

2) nazwy typów dzieł scenicznych:

np.: spektakl, opera, operetka, humoreska, bluetka, pantomima, rewia;

3) nazwy osób pracujących w teatrze oraz typów aktorów:

np.: aktor, aktor charakterystyczny, amant, arlekin, dekorator, bileter, garderobiana, primadonna, sufler, choreograf, librecista, dramaturg, baletmistrz, charakteryzator, modelator, solista;

4) nazwy elementów architektury teatralnej:

np.: scena, loża, loża honorowa, proscenium, kurtyna, rampa, kanat orkiestrowy, charakteryzatornia, foyer, kulisy, deski sceniczne, galeria, rekwizytornia;

myśli D. Bralewskiego zawartych w książce Od przekładu do stownika. Korpus równoległy w redakcji słowników tłumaczeniowych i bardzo szczegółowo wyjaśnily, czym jest słownik przekładowy i dwujęzyczny. Na tej podstawie będziemy rozgraniczać oba terminy. Ilekroć zatem w tekście padnie określenie słownik przekładowy, będzie ono rozumiane jako dzieło powstałe na podstawie tekstów oryginałów i ich tłumaczeń, mające być pomocą w tłumaczeniu poprzez prezentację gotowych rozwiązań, kontekstów, powiązań z kulturą, przykładów użyć oraz dzięki umieszczeniu kwalifikatorów. Ten typ słownika prezentuje relacje międzytekstowe. Słownik dwujęzyczny z kolei jest dziełem normatywnym, bazującym często na już istniejących pozycjach leksykograficznych. Ukazuje relacje na poziomie systemu, bywa uboższy o konteksty użycia niż słownik przekładowy, a jego główną zawartość stanowią utrwalone odpowiedniki językowe lub te, które zostały w nim umieszczone poprzez wybór leksykografa (Kubicka, Walkiewicz, 2015, 317-318). 
5) nazwy elementów techniki teatralnej:

np.: butaforia, rekwizyty, maski, zapadnia;

6) nazwy dotyczące recepcji spektakli:

np.: krytyk teatralny, widownia, klaka, bisować, aplauz, teatroman;

7) nazwy głosów śpiewaczych:

np.: alcista, alt, baryton, bas, bas baryton, mezzosopran, sopran, tenor;

8) nazwy odnoszące się do śpiewu i higieny głosu:

np.: wokaliza, emisja, rejestr, koloratura, fiorytura, belcanto, fonacja, barwa gtosu, falset, postawić głos, tembr;

9) nazwy określające rodzaje teatrów i scen:

np.: teatr amatorski, teatr kukietkowy, amfiteatr, filharmonia, teatr studio, teatr rozmaitości, teatr jednego aktora;

10) ogólne nazwy odnoszące się do teatru i opery:

np.: afisz, występy gościnne, tantiema, charakteryzacja, choreografia, obsada, abonament, adaptacja sceniczna, benefis, deklamacja, dykcja, grać, gestykulować, inscenizacja, premiera, kasowa sztuka, kótko teatralne, kreacja, recytacja, tournée, kwestia, niesceniczność.

Są to oczywiście główne grupy leksykalne, które odzwierciedlają stan leksyki zawartej w słownikach. W analizowanym korpusie można by wyróżnić dodatkowe klasy, np. nazwy składów osobowych zespołów wykonawczych (duet, tercet, trio), nazwy odnoszące się do dzieła teatralnego i operowego (punkt kulminacyj$n y$, rozwiazanie akcji, lejtmotyw) $\mathrm{i}$ in., ale z uwagi na ich nieliczne reprezentacje nie wyodrębniano tych grup.

Między innymi z powodu dość dużej liczby jednostek zawartych w słownikach powzięto decyzję o potraktowaniu PIPR oddzielnie. Analiza zawartości poszczególnych tomów wykazała, że interesująca nas tematyka nie doczekała się jeszcze szczegółowego opracowania w PIPR. Wskażemy teraz na jedyne punkty wspólne tematycznie, które możemy odnaleźć w poszczególnych zeszytach:

- Zeszyt 2. zawiera rozdział poświęcony ludziom filmu i teatru - nie znalazł się on jednak w polu naszych zainteresowań, ponieważ nie podejmujemy tematyki nazw własnych; rozdział dotyczący muzyki scenicznej również nie zawiera interesujących nas jednostek;

- Zeszyt 3. zawiera rozdział poświęcony scenie rockowej, w którym możemy odnaleźć nieliczne reprezentacje pokrywające się z tematyką badaną przez nas, jak np. a cappella - а капемла $x^{2}$ a-капемла, ilustracja тиzусzпа -музыюкальная ильюстрачия, rock opera - poк-опера;

- Zeszyt 4. scena rockowa - zawiera wyłącznie antroponimy odnoszące się do muzyki rockowej.

\footnotetext{
2 Znaczniki zgodnie z oryginalnym zapisem.
} 
Został też wydany Polsko-rosyjski słownik par przekładowych pod red. W. Chlebdy, jest to tom zbiorczy Podręcznego idiomatykonu... (z. 1-5), jednak w nim również nie zanotowano leksyki z zakresu teatru i opery. W związku z powyższym szczegółową analizę leksyki teatralnej i operowej przeprowadzimy na podstawie korpusu wyekscerpowanego z WSPR WP i WSPR PWN.

Zebrany materiał jest pokaźny objętościowo, już pobieżna analiza pokazuje, że leksyka teatralna i operowa nie została w słownikach potraktowana marginalnie, poświęcono jej należną uwagę i włączono do ich zawartości, przy czym słownik WSPR WP zawiera więcej leksemów. Zapewne ma to związek z dwutomową edycją słownika WSPR WP, podczas gdy słownik WSPR PWN jest jednotomowy. Na niemałą objętość jednostek z pewnością wpływa fakt, że słowniki notują warianty słowotwórcze, np.

- aktor, aktoreczka, aktorka, aktorski, aktorstwo, aktorszczyzna, aktorzyca, aktorzyna;

- charakteryzacja, charakteryzator, charakteryzatorka, charakteryzatornia, charakteryzatorski, charakteryzować, charakteryzować się, charakteryzowanie;

- gest, gestykulacja, gestykulacyjny, gestykulować;

- śpiew, śpiewaczka, śpiewaczy, śpiewać, śpiewający, śpiewak, śpiewny.

Należy wyjaśnić, że nie przeprowadzono analizy ilościowej leksemów ani nie uwzględniono $\mathrm{w}$ badaniach kryteriów statystycznych z kilku powodów. Część leksyki teatralnej funkcjonuje $\mathrm{w}$ ramach wieloznaczności, poza tym słowniki podają też konteksty teatralne w hasłach, które nie nasuwają nam na myśl takich skojarzeń, np.

- ciagnąć: ciagnie go teatr - его манит meamp;

- duży: duży głos - большой голос, голос широкого диапазона;

- wszystek: WSZYSTKIE BILETY WYPRZEDANE (napis) - АНШ ААГ.

Wreszcie szczegółowa statystyka na potrzeby niniejszej analizy wydaje się być zbędna.

Jak widać, wyekscerpowany materiał jest różnorodny tematycznie, stosunkowo pokaźny objętościowo oraz umożliwia udzielenie częściowej odpowiedzi na postawione we wstępie artykułu pytania - słowniki nie pomijają sfery teatru i opery, a duża liczba jednostek hipotetycznie może zaspokoić potrzeby użytkowników.

Wyekscerpowaną leksykę można poddawać wielostronnej analizie - pod kątem adekwatności zawartych w słownikach leksemów dla potrzeb użytkowników, poprawności zarejestrowanych ekwiwalentów, kompletności leksyki czy jej aktualności. Każdemu $\mathrm{z}$ tych aspektów $\mathrm{z}$ uwagi na obszerność materiału egzemplifikacyjnego (przytoczone przykłady nie wyczerpują bowiem leksykograficznych kierunków badawczych) mogłoby być poświęcone odrębne studium badawcze. W niniejszej pracy w centrum uwagi znajdzie się ostatni z przytoczonych problemów, mianowicie aktualność leksyki notowanej w słownikach. Celem podjętych badań jest zweryfikowanie, na ile ogólne słowniki polsko-rosyjskie odpowiadają na aktualne potrzeby użytkowników w zakresie interesującej nas leksyki. 
Problematyka aktualności zestawu leksykalnego była wielokrotnie poruszana przez badaczy.

Rozważania na temat doboru haseł do słownika wypada zacząć od przywołania myśli В.П. Беркова, który stwierdza, że najczęstszym kryterium decydującym o włączaniu hasła do siatki jest subiektywne kryterium użyteczności słowa, a kryterium obiektywne mogłaby stanowić częstotliwościowa charakterystyka słowa (Берков, 1973, 21-22).

M. Kozdra zestawia kryteria mające wpływ na dobór haseł, wśród lingwistycznych (wyróżnia ponadto społeczno-polityczne i pragmatyczne) wymienia m.in. „odzwierciedlenie aktualnego stanu słownictwa” (Kozdra, 2017, 211-212). Stwierdza także, że „Słowniki polsko-rosyjskie i rosyjsko-polskie powinny odzwierciedlać aktualny stan słownictwa obydwu języków poprzez uwzględnienie słownictwa wysokofrekwencyjnego" (tamże, 214).

Podobnie M. Łukasik podkreśla wymóg aktualności danych terminograficznych w kontekście słowników specjalistycznych. Terminografowie, jak stwierdza, powinni nieustannie analizować nowo powstające teksty specjalistyczne, co w przypadku terminologii jest niezwykle istotne (Łukasik, 2009, 72).

Również M. Klejnowska-Borowska, mówiąc o konstruowaniu specjalistycznego słownika rosyjsko-polskiego, wielokrotnie podkreśla potrzebę gromadzenia aktualnej leksyki (Klejnowska-Borowska, 2016, 220, 223).

$\mathrm{Z}$ przywołanych myśli jasno wynika, jak ważna jest aktualność leksyki, zwłaszcza w słownikach specjalistycznych. W nawiązaniu do naszego materiału trudno wyrokować o aktualności leksyki, bazując tylko i wyłącznie na zgromadzonym korpusie. Mimo że analiza zbioru leksyki pozwala przypuszczać, iż obecność słownictwa o różnym stopniu zaawansowania i różnym stopniu specjalizacji (np. z jednej strony scena, kulisy, filharmonia, z drugiej - fiorytura, belcanto, intermezzo) zaspokoi, przynajmniej podstawowe, oczekiwania użytkowników, związane z zapotrzebowaniem na leksykę teatralną i operową, to takie twierdzenie bez poddania go weryfikacji byłoby jednak ryzykowne.

Aby sprawdzić jego prawdziwość, przeprowadzono następujące badanie: losowo wybrano kilka współczesnych tekstów w języku polskim o interesującej nas tematyce, które potencjalnie mogłyby zostać przetłumaczone. Również potencjalnie tłumacz tych publikacji mógłby sięgnąć po wielkie dwujęzyczne lub przekładowe słowniki polsko-rosyjskie (ponieważ słowników specjalistycznych w tych obszarach na razie nie ma). Teksty te pochodziły z dwóch czasopism:

a) „Teatr”, nr 2/2020 (1226) - artykuły:

- Dorota Kozińska, Jużza późno, już się stało (w ramach Roku Moniuszkowskiego);

- Kalina Zalewska, Ptonie stodoła (dział: Po premierze; spektakl Gdy przyjdzie sen, Teatr Ludowy w Krakowie);

- Magda Huzarska-Szumiec, Krakowski splin (dział: Po premierze; spektakl Krakowska lekkość bytu, Teatr Ludowy w Krakowie); 
- Nie tylko dla widzów z Nowej Huty - z Małgorzatą Bogajewską, dyrektorką Teatru Ludowego w Krakowie, rozmawia Kalina Zalewska;

- Jacek Cieślak, Koniec mitości, początek śmierci (dział Przegląd; spektakl Salome Krzysztofa Warlikowskiego);

b) „Opera Café”, Opera Śląska w Bytomiu, nr 36, styczeń/luty 2017 - artykuły:

- Muzyka inspiruje i wyzwala emocje, z Tomaszem Koniną, reżyserem operowym i teatralnym, rozmawia Regina Gowarzewska;

- Melodie z Wiestawem Ochmanem;

- Porozmawiajmy o operze;

- Wujek.81. Czarna ballada (Po premierze).

Podobnie jak ze słowników, tak i z tych tekstów wynotowano leksykę: słowa i wyrażenia odnoszące się do teatru i opery, a następnie sprawdzono, czy są one obecne w słownikach polsko-rosyjskich. Taki zabieg pozwolił w pewnym stopniu się przekonać, czy słownictwo zawarte w słownikach jest funkcjonalne.

Co zatem wykazała analiza leksyki z tekstów współczesnych w konfrontacji z leksyką słownikową? Rozważania na temat materiału można by skoncentrować wokół trzech grup, które poniżej zilustrowano przykładami:

1. Pojęcia teatralne i operowe funkcjonujące w słownikach jako hasła jednokomponentowe (będące punktem wyjścia artykułów hasłowych):

adaptacja, akt, aktor, arcydzieto, artysta, choreograf, debiut, didaskalia, dramat, debiut, duet, dzieło, farsa, festiwal, gra, inscenizacja, interpretacja, kierować, komedia, kompozytor, kostium, kreować, krytyk, krytykować, libretto, napisać (w znaczeniu: sztukę, dramat), opera, orkiestracja, partia, pieśń, premiera, realizacja, repertuar, rewia, reżyser, scena, scenograf, sprawozdawca, śpiewak, teatr, tragedia, trupa, twórczość, utwór, widownia, wykonawca, wystawić, zaadaptować, zainscenizować itd.

2. Polączenia wyrazowe:

arie operowe, partia solowa, śpiewaczka operowa, zejść z afisza, zespót baletowy itd.

3. Jednostki tekstu, które nie mają swoich bezpośrednich reprezentacji w słownikach:

a) jednostki motywowane wyrazami ze słowników: dialogować, petnospektaklowy, uteatralizowanie, wyreżyserować, zorkiestrować itd.

b) grupy połączeń wyrazowych:

arcydzieto operowe, brawurowa interpretacja parti, chodzić do opery, czołówka polskich śpiewaków, debiutować w operze, dramat muzyczny, (sztuka) w interpretacji (czyjej), gra wykonawców, (sztuka) w ujęciu (czyim), (sztuka) w nowych inscenizacjach, kierować teatrem, kostium $z$ epoki, partie tenorowe, spektakl muzyczny, przestrzeń sceny, opera narodowa, partie śpiewane, polskie sceny operowe, premiera spektaklu $w$ reżyserii, prestiżowe sceny, repertuar komediowy, spektakl zrealizowany, światowej stawy tenor, twórcy spektaklu, wyreżyserować utwór, wystawić dramat, zawojować światowe sceny, zespót ... pod batuta, abstrakcyjne projekcje, autorska koncepcja dramaturgiczna, bezradność warsztatowa, estetyka przedstawień, konflikt tkwiacy u sedna narracji, konwencje sceniczne, kreować pierwszoplanowe partie teno- 
rowe, odbiór dzieła teatralnego, oszczędny gest aktorski, podawać tekst, postać osiowa dramatu, premiera ... spadla $z$ afisza, premiera petnospektaklowa, prowadzić teatr, pojedynczy spektakl, realizować swoje partie, rekonstrukcja opery, robić teatr, spektakl osadzony w scenerii, wersja przeprogramowana dramaturgicznie przez reżysera, wersja sceniczna, wspótpraca dramaturgiczna itd.

Wyekscerpowaną leksykę nieprzypadkowo podzielono na takie właśnie trzy grupy, ma to bowiem związek z możliwością (lub jej brakiem) odnalezienia odpowiedników tych słów w słownikach. Do pierwszej grupy należą słowa (rzeczowniki i czasowniki) bez kontekstu. Słowniki notują te wyrazy, zatem nie sprawia trudności dotarcie do ich semantyki w języku obcym, czyli rosyjskim. Pojęcia te są w powszechnym użyciu, a ich znaczenie powinno być zrozumiałe dla większości użytkowników języka. Nie dziwi więc, że znalazły się one w ogólnych słownikach polsko-rosyjskich. Jednostki zaklasyfikowane do drugiej grupy są, co prawda, obecne w słownikach, jednak ich odnalezienie wymaga bardziej wnikliwego spojrzenia w strukturę artykułu. To pojęcia używane powszechnie i być może ten fakt zadecydował o włączeniu ich do zasobów leksykograficznych. Nie odnajdziemy za to w słownikach polsko-rosyjskich odpowiedników jednostek z grupy trzeciej. W grupie 3a znalazły się nieliczne reprezentacje słów i wyrażeń motywowanych, ale zwróćmy uwagę na to, że dla osoby dobrze znającej język rosyjski nie powinny stanowić problemu wyrazy z pierwszej czy nawet drugiej grupy, ale właśnie te występujące rzadziej nawet w języku ojczystym, spotykane najczęściej w dyskursie specjalistycznym. Ostatnią grupę - 3b - stanowią wyrażenia, które trudno byłoby przetłumaczyć za pomocą słowników, ponieważ w tej gotowej formule połączeń nie są przez nie notowane (WSPR WP i WSPR PWN).

W taki sposób przedstawia się ogólna charakterystyka jednostek wyekscerpowanych $\mathrm{z}$ autentycznych współczesnych tekstów w konfrontacji ze słownikami. Możemy poczynić wstępny wniosek - nie można przetłumaczyć takiego tekstu, bazując wyłącznie na propozycjach odpowiedników notowanych w słownikach polsko-rosyjskich. Nie wszystkie słowa, które pojawiły się w tekście, są zarejestrowane w słownikach, jeszcze większa trudność dotyczy wyrażeń i połączeń wyrazowych, zarówno ustabilizowanych, jak i nowatorskich, tworzonych na potrzeby danego tekstu. W zgromadzonym materiale udało się zauważyć również inne usterki, które warto odnotować, nie w celu formułowania głosów krytycznych w stronę konkretnych słowników, ale raczej z myślą o wyciągnięciu wniosków konstruktywnych z punktu widzenia przyszłych prób tworzenia siatek haseł do nowych słowników. Pierwsze spostrzeżenie dotyczy aktualności leksyki zawartej w słownikach: niektóre leksemy opatrzono kwalifikatorami przest. lub $y \mathrm{~cm}$. - oznaczone są zatem jako słowa przestarzałe, niebędące w powszechnym użyciu już w momencie wydania słownika. Są to takie wyrazy, jak np.: farsista, kontramarka, międzyakt $\mathrm{i}$ in. Nie odnotowano tych jednostek $\mathrm{w}$ badanych artykułach ani innych współczesnych tekstach. Tworząc aktualne słowniki, należy się zatem zastanowić nad zasadnością umieszczania w nich tych jednostek. 
Kolejną problematyczną i kłopotliwą dla użytkownika sytuacją jest ta, kiedy w słownikach proponowane są odmienne odpowiedniki. W badanych źródłach dostrzegamy takie rozbieżności. Dla przykładu w WSPR PWN czytamy: baletki - пуанты/балетки (разг); bas - 1 бac 2 (głos) басок; етіsja - эмиссия; rekwizytornia - бутафорскал, zaś w WSPR WP: baletki - балетные myфıи; bas - 1 бac (голос, инструмент) 2 бас (певец) 3 чаще bаsу - басы (струны); етіsја - w 4 znaczeniu: муз. постановка (голоса); rekwizytornia-театр. помещениедля хранения реквизита. Użytkownik może czuć się zdezorientowany, kiedy, chcąc porównać propozycje w dostępnych słownikach, widzi tak różne ekwiwalenty.

Czy zatem słownik dwujęzyczny jest pomocą, z której warto korzystać, zważywszy na liczne jego usterki i niedociągnięcia? B. Gasek stwierdza (co prawda w kontekście zajęć translatorycznych, ale myśl tę możemy przenieść również na inne sytuacje przekładu), że wielki słownik dwujęzyczny jest oczywistą pomocą, z której korzystamy, kiedy potrzebujemy znaleźć znaczenie słowa. Ponadto stanowi także rodzaj podręcznika języka obcego i tłumaczenia, gdyż użytkownik nierzadko zapamiętuje informacje w nim zawarte, w tym także błędne (Gasek, 2014, 44). Zatem mimo przeświadczenia, że słownik dwujęzyczny lub przekładowy nie wystarczy, by tłumaczyć teksty, nie ulega wątpliwości, że jest to narzędzie, którym użytkownicy posługują się stosunkowo często, czy to w celu sprawdzenia znaczenia słowa, czy aby podczas procesu tłumaczenia dokonać wstępnego rozeznania, jakiego typu odpowiedniki proponuje taki słownik.

Wnioski, które wypływają z przeprowadzonej analizy, są w zasadzie niejednoznaczne. $Z$ jednej strony bowiem zdecydowana większość słów, które wystąpiły w badanych artykułach jest obecna w słownikach. $Z$ drugiej zaś strony - słowa w tekście nie występują w izolacji, ale wchodzą w różne, mniej lub bardziej skonwencjonalizowane połączenia wyrazowe. Słowniki, których hasła mają układ gniazdowy, notują te najczęściej spotykane kolokacje, jednak jest to zaledwie niewielka część używanych połączeń wyrazowych. Połączenia wyrazowe $\mathrm{z}$ różnych dziedzin notuje PIPR, jednak sfera teatru i opery na razie nie została w nim opracowana.

Można zatem postulować, by do słowników dwujęzycznych i przekładowych, które już powstają i będą powstawać, włączać jak najwięcej połączeń wyrazowych, zaczerpniętych choćby ze wspólczesnych tekstów, ponieważ to właśnie kolokacje sprawiają użytkownikom słowników największe trudności. Uwaga ta dotyczy naturalnie nie tylko interesującej nas sfery, ale także innych dziedzin życia. Umieszczenie w słowniku większej liczby połączeń wyrazowych na pewno zwiększyłoby jego objętość (tu dochodzą problemy wydawnicze, budżetowe), ale aktualizacja siatki haseł, usunięcie słów, które wyszły z użytku (nie tylko tych, które już są oznaczone jako przestarzałe, lecz także zbadanie pod tym kątem pozostałych hasel) mogłoby umożliwić rozszerzanie haseł w przypadkach, w których jest to konieczne. Oczywiste jest jednak, że nie da się uwzględnić wszystkich połączeń, w które może wchodzić jednostka wyrazowa, dotyczy to zwłaszcza 
dłuższych wyrażeń. Należy dokonać selekcji doboru haseł, kierując się kryterium częstotliwości użycia leksemów w konkretnych sytuacjach komunikacyjnych (tekstach). Nie stanowi więc o niskiej jakości słownika fakt, że nie przetłumaczymy z jego pomocą takich wyrażeń, jak: autorska koncepcja dramaturgiczna, rozbudowane czytanie tekstu czy wersja przeprogramowana dramaturgicznie przez reżysera. Jak bowiem stwierdza Wojciech Chlebda:

[...] nie wszystkie ekwiwalenty, które są oferowane przez słowniki przekładowe, sprawdzają się $\mathrm{w}$ tworzeniu przekładu tekstu [...] - i na odwrót: nie wszystkie ekwiwalenty tekstowe nadają się do wprowadzenia na karty słowników przekładowych (Chlebda, 2011, 24).

Spróbujmy odpowiedzieć sobie jeszcze na pytanie, co powinien zrobić tłumacz, który ma zadanie przełożyć np. takie teksty jak te wymienione w niniejszym artykule, jeżeli okazuje się, że dostępne słowniki nie będą dostateczną pomocą. Wydaje się, że najlepszym wyjściem z tej sytuacji byłoby wykorzystanie przez niego tekstów paralelnych, tj. podobnych pod względem tematycznym współczesnym tekstom napisanym $\mathrm{w}$ języku rosyjskim (jako języku oryginału) i wynotowanie z nich połączeń wyrazowych, za których pomocą będzie można stworzyć tekst w języku przekładu.

Badania nad aktualnością zasobów leksykograficznych są istotne, a ich przedmiot - konieczny, także w sferze teatru i opery, obserwujemy bowiem obecnie wzrost zainteresowania kulturą w przestrzeni międzynarodowej. W związku z tym należy się zatroszczyć o wysoki poziom międzykulturowej komunikacji specjalistycznej w danej dziedzinie. Zapewnieniu efektywnej komunikacji mogą służyć badania leksykograficzne, którym poświęcono ten tekst.

\section{Bibliografia}

Chlebda, W. (2011). Ekwiwalencja i ekwiwalenty: między stownikiem a tekstami. W: Na tropach translatów (21-45). W. Chlebda (red.). Opole: Wydawnictwo Uniwersytetu Opolskiego.

Chlebda, W. (red.). (2006). Podręczny idiomatykon polsko-rosyjski. Zeszyt 1. próbny. Opole: Wydawnictwo Uniwersytetu Opolskiego.

Chlebda, W. (red.). (2007). Podręczny idiomatykon polsko-rosyjski. Zeszyt 2. Opole: Wydawnictwo Uniwersytetu Opolskiego.

Chlebda, W. (red.). (2008). Podręczny idiomatykon polsko-rosyjski. Zeszyt 3. Opole: Wydawnictwo Uniwersytetu Opolskiego.

Chlebda, W. (red.). (2009). Podręczny idiomatykon polsko-rosyjski. Zeszyt 4. Opole: Wydawnictwo Uniwersytetu Opolskiego.

Chlebda, W. (red.). (2014). Polsko-rosyjski stownik par przekładowych. Tom zbiorczy Podręcznego idiomatykonu polsko-rosyjskiego (z. 1-5). Opole: Wydawnictwo Uniwersytetu Opolskiego. 
Gasek, B. (2014). Wielkie stowniki rosyjsko-polskie a dydaktyka przekładu. Lingwistyka Stosowana, 11, 43-51.

Hessen, D., Stypuła, R. (2004). Wielki słownik polsko-rosyjski. Warszawa: Wiedza Powszechna

Klejnowska-Borowska, M. (2016). Zasady konstruowania specjalistycznego słownika rosyjsko-polskiego dla celów dydaktycznych (na materiale terminologii papierów wartościowych). Studia Wschodniosłowiańskie, t. 16, 215-231.

Kozdra, M. (2017). Dobór haset w słownikach ogólnych rosyjsko-polskich i polsko-rosyjskich. W: Wokót „300 tysięcy polskich stów”. Wstęp do hastownikologii (205-222). J. Wawrzyńczyk, P. Wierzchoń (red.). Warszawa: BEL Studio.

Kubicka, E., Walkiewicz, A. (2015). Co tłumaczy słownik przekładowy? Uwagi na marginesie pracy Dariusza Bralewskiego, Od przekładu do słownika. Korpus równoległy w redakcji słowników tłumaczeniowych, Łask 2012 („Rozumienie - Interpretacja - Przekład”, t. 9), 643 strony (recenzja książki). Rocznik Przekładoznawczy. Studia nad teorią, praktyką i dydaktyką przekładu, 10, 315-324.

Łukasik, M. (2009). Idealny - optymalny - maksymalny słownik terminologiczny. W: Publikacja jubileuszowa. Na drodze wiedzy specjalistycznej (64-79). M. Eukasik (red.). Warszawa: Katedra Języków Specjalistycznych, Uniwersytet Warszawski.

„Opera Café”, Opera Śląska w Bytomiu, nr 36, styczeń/luty 2017. https:/ /opera-slaska. pl/files/download/opera_cafe_nr_36.pdf (dostęp: 12.03.2020).

Piotrowski, T. (2011). Ekwiwalencja w stownikach dwujęzycznych. W: Na tropach translatów (45-71). W. Chlebda (red.). Opole: Wydawnictwo Uniwersytetu Opolskiego.

„Teatr”, nr 2/2020 (1226).

Wawrzyńczyk, J., Kuratczyk, M., Małek, E., Bartwicka, H. (2005). Wielki słownik polsko-rosyjski. J. Wawrzyńczyk (red.). Warszawa: Wyd. Naukowe PWN.

Берков, В.П. (1973). Вопросы двуязычной лексикографии. Словник. АенинграА: Изаательство $\Lambda$ енинграАского университета.

Тюленев, С.В. (2004). Теория перевода. Москва: Гардарики. 